\title{
PREDICTIVE VALUE OF SERUM HORMONES AND BIOCHEMICAL PROFILES FOR RETAINED PLACENTA IN BUFFALOES
}

\author{
A.A. NASRA*; T.A. HASSAN** and T.A. K GHATTAS** \\ *Department of artificial insemination \& embryo transfer, Animal Reproduction Research Institute, Gizza, Egypt. \\ *** Department of biology of reproduction, Animal Reproduction Research Institute, Gizza, Egypt.
}

\section{ABSTRACT}

Retained fetal membrane (RFM) is one of the most important calving related disorders affecting economics of the farmer and the herd health. The aim of the study was to compare some hormonal and biochemical parameters level in blood

Received at: $26 / 2 / 2013$ serum of buffalo-cows with retained fetal membranes (RFM) and normal non retained animals $(C)$. Blood samples were collected from buffalo-cows $(n=55)$ for

Accepted: 21/3/2013 three times (after four months, seven months of gestation and 24 hour after parturition), after parturition only nine buffalo-cows affected with RFM (16.36\%). The obtained results, showed significance decrease $(\mathrm{P}<0.05)$ in Calcium, Zinc and Selenium between RFM and C groups after four months of gestation, while, in RFM group after seven months of gestation results revealed significance decrease $(\mathrm{P}<$ $0.05)$ in $17-\beta$ Estradiol, calcium and selenium and significance increase $(P<0.05)$ in progesterone, cholesterol and linolinic free fatty acids. But after 24 hour postpartum there was significance decrease $(\mathrm{P}<0.05)$ in cholesterol, linolinic free fatty acids and calcium, with significant increase $(\mathrm{P}<0.05)$ in progesterone and Cortisol. The obtained results concluded that Progesterone and Cortisol were significantly increased remarkably just after 7 th month of pregnancy, in addition to significantly decreased of estradiol $17-\beta$ and biochemical profiles extending till $24 \mathrm{hrs}$ after calving.

Key words: Buffalo-cows, retained placenta, hormones, biochemical parameters.

\section{INTRODUCTION}

One of the most common problems seen during the post - parturient period of high-yielding dairy buffaloes is RFM. It causes important economic losses due to decreased pregnancy rates, increased calving - conception intervals and a rapid drop in milk yield (Semacan and Sevinc, 2005; Seifi et al., 2007 and Rabbani et al., 2010). Most buffaloes usually expel the fetal membranes within 8 hours following parturition. Retention of fetal membranes for 12 hours or more after parturition indicates abnormal condition which is one of the most important calving related disorders affecting economics of the farmer and the herd health (Laven and Peters, 1996). The productive and reproductive performance of the buffalo is negatively influenced by the calving related reproductive disorders, especially retention of fetal membranes (El-Wishy, 2007). The incidence of retention of fatal membranes and genital prolapse is high in the buffalo compared to cattle (Samad et al., 1987; Arthur et al., 1989; Laven and Peters, 1996 and Rabbani et al., 2010).

The incidence of retained fetal membranes increases with parity, twins and premature births and varies from country to country, year to year and from herd to herd (Hussain, 1983). Physiologically, steroids are fundamental in pregnancy maintenance and parturition where it regulate prostaglandin synthesis, which stimulated by low level of progesterone (Wango et al., 1992 and Wooding et al., 1996) and estrogens function to increase the prostaglandine F2 $\alpha$ (PGF2 $\alpha$ ) levels in the uterus pre-parturition (Ham et al., 1975 and Rasmussen et al., 1996). But progesterone levels in animals with retained fetal membrane are higher (Elecko et al., 1982 and Matton et al., 1987), estrogen levels are lower (Thomas et al., 1992 and Kankofer et al., 1996) than normal. Decreased level of estrogen and delay in lyses of the corpora lutea resulting in increased level of progesterone are suggested to be associated with calving related disorders like dystocia and retention of fetal membrane in dairy cows (Zhang et al., 1999 and Ali et al., 2009) with a higher significant levels of Cortisol throughout the peri-partum period (Peter and Bosu, 1987). Energy disturbances can start a few weeks before calving reported that cows with RFM showed a high level of ketone bodies (KB) and free fatty acids (FFA) in the last week before parturition. Hypoglycaemia was not observed in RFM cows with high blood concentration of FFA (Kuzma et al., 1996 and Kaczmarowski et al., 2006). It can be related to the high level of Cortisol (Weber, et al., 2000) which 
is a cause of RFM (Subandrio and Noakes, 1997). Overfeeding during the non-lactating stage reduces feed intake and stress near parturition accelerates the release of NEFA from adipose tissue, resulting in an excess uptake of NEFA by the liver (Rukkwamsuk et $a l ., 1998)$. Circulating NEFA is absorbed by the liver and re-estrified to Triacylglycerols (TAG) which are then secreted in the blood (Herdt et al., 1988). Excess hepatic lipids are stored as TAG and are associated with decreased metabolic functions of the liver (Drackley, 1999) and lead to increase the incidence of health disorders (Jorritsma et al., 2000). Abnormalities in trace element regulation have been reported in various obstetric pathologies in animals (Graham et al., 1994; McSporran et al., 1977; Naziroglu et al., 1998 and Olujohungbe et al., 1998).

The aim of the study was to compare the serum levels of hormones (progesterone, 17- $\beta$ oestradiol and Cortisol); biochemical parameters (Total cholesterol and FFA) and some macro elements ( $\mathrm{Ca}, \mathrm{P})$ and some micro elements $(\mathrm{Cu}, \mathrm{Zn}$ and $\mathrm{Se})$ at different stages during gestation period and just after parturition as a predisposition effect on the development of retained fetal membrane in apparently healthy pregnant buffaloes.

\section{MATERIALS and METHODS}

\section{Animals and management}

A total of fifty five pregnant Buffaloes were used for the current experiment without any interference during gestation period or parturition. This study was conducted at El Gharbyia Province (Qtoor city). The buffaloes were confined to partly roofed structures with open sides and free-stall barns with a concrete floor. They were fed a ration consisting of hay of barseem (Trifolium Alexandrium); silage (Green Maize) and concentrates (prepared mainly from maize, soybean, and wheat bran). All buffaloes were artificially inseminated from sound healthy bulls and were milked by machine twice daily along seven months, then dried off milk for the rest days of gestation. At 10 days prior to expected day of parturition, every buffalo kept in separate calving pen until 2 days after parturition.

\section{Blood collection}

Blood samples (approximately $10 \mathrm{ml}$ ) were collected from Jugular veins into plain vaccutainer tubes using its special needles. The blood samples were collected once, after four months, seven months of gestation and $24 \mathrm{hrs}$ after parturition. The blood was centrifuged and the obtained serum samples were stored at $-20{ }^{\circ} \mathrm{C}$ until hormones and biochemical analyses were done.

\section{Biochemical analysis}

Calcium (Ca), inorganic phosphorus (P) and total cholesterol were estimated by commercial kits calorimetrically according to Gindler and King (1972), Goldenberg (1966) and Watson (1960), respectively. Cupper $(\mathrm{Cu})$, zinc $(\mathrm{Zn})$ and selenium (Se) concentrations were analyzed by atomic absorption (spectrophotometery) as described by Bauer, (1982). Free fatty acids "Linolinic and Linoleic FA" were estimated by Gas chromatography according to Hollender et al. (2002).

\section{Hormonal analysis}

Serum concentrations of progesterone, 17- $\beta$ estradiol and cortisol were determined by immunoenzymatic methods (Biodata Diagnostic tests). The sensitivity of these tests were: progesterone $0.15 \mathrm{ng} / \mathrm{ml}, \mathrm{C} . \mathrm{V} . \%-$ $3.9 ; 17-\beta$ oestradiol $5 \mathrm{pg} / \mathrm{ml}, \mathrm{C} . \mathrm{V} . \%-3.9$ and cortisol $0.36 \mathrm{ng} / \mathrm{ml}$ C.V.\% - 3.7 .

\section{Definitions, assumptions, and groups}

Buffaloes were intensively observed for expulsion of fetal membranes until $12 \mathrm{~h}$ after calving. Buffaloes expel their fetal membranes within $12 \mathrm{~h}$ after calving were considered normal parturition $(n=46)$. The fetal membranes were not expelled within $12 \mathrm{~h}$ after calving were considered a RFM $(n=9)$.

\section{Statistical analysis:}

All obtained data was subjected to "T. test between Retained foetal membrane and normal groups" according to Snedecore and Cochran (1987).

\section{RESULTS}

Out of 55 parturitions in buffalo-cows, 9 buffaloes (16.36\%) took a long time for expelling the fetal membranes (18.5-21.0 hrs). While, 46 buffaloes $(83.64 \%)$ showed a normal averages of time (10.13 hours) for expelling the fetal membranes. Tables 1,2 and 3 showed significances in hormonal and biochemical value levels of blood serum examinations during four, seven months of gestation and $24 \mathrm{hr}$. after parturitions. 
$\underline{\text { Assiut Vet. Med. J. Vol. } 59 \text { No. } 137 \text { April } 2013}$

Table 1: Mean ( \pm SE) blood serum level of hormonal and chemical values after four months of gestation in Buffalo-cows with retained fatal membrane (RFM) or without (control, C)

\begin{tabular}{ccc}
\hline Item & RFM & Control (C) \\
\hline $\mathrm{E}_{2}(\mathrm{ng} / \mathrm{ml})$ & $11.70 \pm 0.83$ & $11.31 \pm 0.05$ \\
\hline $\mathrm{P}_{4}(\mathrm{ng} / \mathrm{ml})$ & $7.36 \pm 0.53$ & $7.12 \pm 0.24$ \\
\hline Cortisol $(\mathrm{ng} / \mathrm{ml})$ & $15.92 \pm 0.24$ & $15.78 \pm 2.22$ \\
\hline T.cholesterol $(\mathrm{mg} / \mathrm{dl})$ & $106.17 \pm 5.39$ & $104.895 \pm 1.64$ \\
\hline Linolinic FA $(\mathrm{ng} / \mathrm{ml})$ & $74.64 \pm 3.82$ & $74.73 \pm 1.03$ \\
\hline Linoleic FA $(\mathrm{ng} / \mathrm{ml})$ & $102.47 \pm 1.68$ & $95.12 \pm 1.77$ \\
\hline $\mathrm{Ca}(\mathrm{mg} / \mathrm{dl})$ & $7.16 \pm 0.11$ & $8.48 \pm 0.25^{* *}$ \\
\hline $\mathrm{Ph}(\mathrm{mg} / \mathrm{dl})$ & $3.89 \pm 0.19$ & $4.44 \pm 0.13$ \\
\hline $\mathrm{Cu}(\mu \mathrm{g} \%)$ & $168.33 \pm 6.32$ & $161.02 \pm 3.20$ \\
\hline $\mathrm{Zn}(\mu \mathrm{g} \%)$ & $191.89 \pm 5.97$ & $212.04 \pm 3.03^{* *}$ \\
\hline $\mathrm{Se}(\mu \mathrm{g} \%)$ & $223.11 \pm 9.22$ & $246.22 \pm 4.59^{* *}$ \\
\hline$* *$ significance $(\mathrm{P}<0.05)$. & &
\end{tabular}

Regarding to the studied parameters in Table 1 of RFM and normal animals after four months of gestation, only there were significance decrease $(\mathrm{P}<0.05)$ in the level of Calcium, Zinc and Selenium in RFM than normal, while there were no significant differences in the others parameters.

Table 2: Mean ( \pm SE) blood serum level of hormonal and chemical values after seven months of gestation in Buffalo-cows with retained fatal membrane (RFM) or without (control, C)

\begin{tabular}{ccc}
\hline Item & RFM & Control (C) \\
\hline E2 $(\mathrm{ng} / \mathrm{ml})$ & $24.42 \pm 1.13$ & $93.29 \pm 2.42^{* *}$ \\
\hline $\mathrm{P} 4(\mathrm{ng} / \mathrm{ml})$ & $8.20 \pm 0.65^{* *}$ & $5.42 \pm 0.13$ \\
\hline Cortisol $(\mathrm{ng} / \mathrm{ml})$ & $29.10 \pm 1.38^{* *}$ & $7.11 \pm 0.09$ \\
\hline T.cholesterol $(\mathrm{mg} / \mathrm{dl})$ & $126.89 \pm 3.96^{* *}$ & $103.80 \pm 1.43$ \\
\hline Linolinic FA $(\mathrm{ng} / \mathrm{ml})$ & $55.14 \pm 3.05^{* *}$ & $69.31 \pm 1.28$ \\
\hline Linoleic FA $(\mathrm{ng} / \mathrm{ml})$ & $96.50 \pm 6.33$ & $98.53 \pm 2.28$ \\
\hline $\mathrm{Ca}(\mathrm{mg} / \mathrm{dl})$ & $6.73 \pm 0.35$ & $9.13 \pm 0.11^{* *}$ \\
\hline $\mathrm{Ph}(\mathrm{mg} / \mathrm{dl})$ & $4.10 \pm 0.26$ & $4.397 \pm 0.12$ \\
\hline $\mathrm{Cu}(\mu \mathrm{g} \%)$ & $178.78 \pm 7.96$ & $180.93 \pm 2.95$ \\
\hline $\mathrm{Zn}(\mu \mathrm{g} \%)$ & $206.89 \pm 6.94$ & $208.30 \pm 3.43$ \\
\hline $\mathrm{Se}(\mu \mathrm{g} \%)$ & $226.78 \pm 18.62$ & $290.93 \pm 10.72^{* *}$ \\
\hline$* *=$ significance $(\mathrm{P}<0.05)$ & &
\end{tabular}

As shown in Table 2, buffaloes that showed RFM had a significance decrease $(\mathrm{P}<0.05)$ in the level values of estradiol. But contrarily there were significance increase $(\mathrm{P}<0.05)$ in the level values of progesterone; Cortisol; T.cholesterol; Linolinic FA in RFM than control group. In the mean while, significant decrease $(\mathrm{P}<0.05)$ in the level values of Calcium and Selenium between the two groups respectively.

Other parameters (linoleic FA; phosphorus; cupper and Zinc) showed no significant in the level values during this stage of pregnancy. 
Table 3: Mean ( \pm SE) blood serum level of hormonal and chemical values 24 hour postpartum in Buffalo-cows with retained fatal membrane (RFM) or without (control, C)

\begin{tabular}{ccc}
\hline Item & RFM & Control (C) \\
\hline $\mathrm{E}_{2}(\mathrm{ng} / \mathrm{ml})$ & $76.10 \pm 4.48$ & $73.97 \pm 2.55$ \\
\hline $\mathrm{P}_{4}(\mathrm{ng} / \mathrm{ml})$ & $2.52 \pm 0.27^{* *}$ & $1.66 \pm 0.13$ \\
\hline Cortisol $(\mathrm{ng} / \mathrm{ml})$ & $50.62 \pm 6.22^{* *}$ & $30.10 \pm 1.81$ \\
\hline T.cholesterol $(\mathrm{mg} / \mathrm{dl})$ & $102.28 \pm 3.22$ & $135.89 \pm 1.85^{* *}$ \\
\hline Linolinic $\mathrm{FA}(\mathrm{ng} / \mathrm{ml})$ & $62.36 \pm 2.53$ & $70.10 \pm 1.26^{* *}$ \\
\hline Linoleic $\mathrm{FA}(\mathrm{ng} / \mathrm{ml})$ & $94.80 \pm 3.05$ & $86.57 \pm 2.06$ \\
\hline $\mathrm{Ca}(\mathrm{mg} / \mathrm{dl})$ & $6.69 \pm 0.40$ & $8.42 \pm 0.08^{* *}$ \\
\hline $\mathrm{Ph}(\mathrm{mg} / \mathrm{dl})$ & $3.71 \pm 0.20$ & $3.71 \pm 0.06$ \\
\hline $\mathrm{Cu}(\mu \mathrm{g} \%)$ & $162.33 \pm 3.40$ & $175.30 \pm 2.34^{* *}$ \\
\hline $\mathrm{Zn}(\mu \mathrm{g} \%)$ & $207.44 \pm 7.83$ & $202.87 \pm 3.25$ \\
\hline $\mathrm{Se}(\mu \mathrm{g} \%)$ & $215.44 \pm 13.59$ & $305.65 \pm 9.20^{* *}$ \\
\hline$* *$ significance $(\mathrm{P}<0.05)$ & &
\end{tabular}

After 24 hrs postpartum (Table 3) the mean level values of Progesterone and Cortisol still increase significantly $(\mathrm{P}<0.05)$ as in the seventh month of pregnancy in RFM than control group, while, the level values of T.cholesterol; Linolinic FA; Calcium; Cupper and Selenium showed significant decrease $(\mathrm{P}<0.05)$ in RFM than control group than just after the $7^{\text {th }}$ months of pregnancy. But, other parameters (Estradiol; Phosphorus and Zinc, also, Linoleic FA) after $24 \mathrm{hrs}$ postpartum showed no significance in the mean level values of blood serum in buffaloes with RFM or without.

\section{DISCUSSION}

The present findings for the incidence of RFM $(16.36 \%)$ were similar to these reported in buffaloes (16.18\%) by Oresnik (1995) and Sabry et al. (1997). The reciprocal changes in estradiol and progesterone synchronize the parturition process. Asynchrony of this hormonal mechanism can lead to calving problems (Olujohungbe et al., 1998). The results of the present study of buffalo-cow were significantly increase $(\mathrm{P}<0.05)$ in mean values of blood serum progesterone before and after calving in the buffaloes with RFM than without, these results were parallel to that obtained by Ali et al. (2012) in Pakistan.

The reason behind this increased level of progesterone concentration is reduced level of Estradiol-17 $\beta$ and delayed regression of corpora lutea in dystocia (Zhang et al., 1999) or in spontaneous parturition (El-Wishy, 2007). In this study, serum estradiol-17 $\beta$ concentrations were found to be lower in buffaloes affected with RFM compared with buffaloes without RFM, but appear significantly $(\mathrm{P}<0.05)$ just after the $7^{\text {th }}$ month of pregnancy. This lower level of estrogen is also reported earlier (Erb et al., 1981) and these concentrations caused reduced synthesis of PGF2 $\alpha$ resulting in calving difficulty (Wischral et al., 2001) and consequently RFM.
Contrarily, higher estradiol and lower progesterone concentration in dystocial cattle as compared to controls were reported by Yokus et al. (2010).

Increased progesterone level in RFM may be due to failure of the placenta to produce specific steroidal enzymes that help in progesterone metabolism and its conversion to estrogen (Matton et al., 1987), which in turn may induce the accumulation of immunosuppressive proteins in the uterine lumen which make the uterus susceptible to infection and persistence of bacteria (Königsson et al., 2002).

El-Nemer et al. (2000) observed that during the week before parturition, the level of estradiol reaches its maximum level and this help the uterus to get rid of any remnant of fetal membranes and also to prevent endometriosis. Therefore, a decreased level of estrogen may be indicated as a factor enhancing RFM.

Similar to the results that were obtained by Kornmatitsuk et al. (2000); Sabry et al. (1997); Michal et al. (2006) and Kankofer et al. (1998) in RFM cows, buffaloes with RFM in present study showed a homogeneous increase in the progesterone and Cortisol and a decrease in the estradiol $17 \beta$ levels. The increased cortisol may be related to the 
stress in buffalo-cows with RFM (Dobson and Smith 2000). Similar data were previously recorded by Farzaneh et al. (2002) and Kandeil et al. (2002).

The frequency of RFM can increase as a result of insufficient feeding of high-efficient animals, also, the energetic mineral and the wrong balance of an alimentary dose lead to metabolic disorders, loss of acid-base equilibrium, hormonal system changes and even to suppress activity of the immune system (Levis, 1997). It was reported that prepartum FFA (Laszlo et al., 2009 and Ospina et al., 2010) was significantly associated with development of clinical diseases in dairy cows including retained placenta (Ospina et al., 2010). Serum levels of FFA may be more useful to identify buffalo-cows with a metabolic abnormality or energy imbalance that might predispose them to RFM (Quiroz-Rocha et al., 2009). In this study, $\mathrm{T}$ triglycerides level significantly decreased in buffalo-cows with RFM than control, similar to the data in RFM cows obtained by Macak et al. (1999). Furthermore, significant changes in serum cholesterol concentrations could be simply due to decrease of feed intake, because most cholesterol in ruminants is of intestinal origin (Uchide et al., 1997). It is well known that feeding problems during the peri-parturient period may affect susceptibility of cows to metabolic disorders (Dann et al., 2005) including RFM. The decreased cholesterol level may be owing to the persistence utilization of cholesterol for progesterone synthesis or due to increase breakdown of cholesterol (Kandeil et al., 2002).

Minerals are important in the prevention of RFM (Wilde, 2006). Most minerals act as co-factors or activators of enzymes systems and elements. Calcium sensitizes female tubular genitalia for the action of hormone like oxytocin. So, calcium deficiency can act as a predisposing factor for uterine inertia leading to dystocia, retention of fetal membranes and metritis (Dabas et al., 1987 and Mohanty et al., 1994). So, the significant decrease of serum calcium level was parallel to the results observed by Mandali et al. (2002) in cattle and buffalo affected with retention of fetal membrane. Another works by Patel et al. (1999); Akar et al. (2002) and Melendez et al. (2004) reported significantly low level of blood serum calcium and inorganic phosphorus four weeks post partum in buffaloes which had retention of fetal membrane during parturition. In accordance with the present study, they recorded a non significant decrease in $\mathrm{Zn}, \mathrm{P}$ and decrease in $\mathrm{Ca}, \mathrm{Cu}$ in dystocia at the prepartum period as compared to non dystocial ones, which implies evaluation of these elements in $7^{\text {th }}$ month of pregnancy, does not appear to be useful in the assessment of dystocia. Others as Hattab and Abdel Moghney, (1994); Markiewicz et al. (2001); Farzaneh et al. (2002) and Roche, (2006) were recorded that RFM animals show concurrent decreased zinc and selenium, this complex factors might lead to RFM. While the results of a similar studies on the predispose to RFM in buffalo-cows pre and post-calving periods by Bari et al. (1996); Sabry et al. (1997); Akar and Yeldiz, (2005) and Tillard et al. (2008) showed significant decrease level in blood serum values of $\mathrm{Ca}, \mathrm{P}, \mathrm{Zn}$ and $\mathrm{Se}$ in accordance with the present results. This decrease of Se, $\mathrm{Zn}$ and $\mathrm{Cu}$ is attributed to the high demand of these elements in enzyme involved in the antioxidants defense system in dairy cows, they added that these elements incorporated in glutathione peroxidase performing the antioxidative defense mechanism by eliminating hydrogen peroxide (Kommisrud et al., 2005). Free radicals which increased towards parturition have a detrimental effect on cellular membrane integrity and compromising the cellular function of steroidogenic tissues and embryos (Arechiga et al., 1998).

Conclusion: the obtained results indicate that the biochemical profiles of T. Cholesterol, linolinic free fatty acids, Calcium, and Selenium mean level values of blood serum were similarly significantly decrease in RFM than control buffalo-cows just after $7^{\text {th }}$ month of pregnancy or just $24 \mathrm{hrs}$ after calving in the same farm. Also, the hormonal profiles of increased significance of progesterone and cortisol, with lower decreased significance of estrogen seem to be the main predictive changes in retained placental buffalocows.

\section{REFERENCES}

Akar, Y.; Yeldiz, H.; Kececi, H. and Aydin, M. (2002): Investigation on Serum Calcium (Ca), Phosphorus (P) and Alkaline Phosphatase (AP) Levels in Cows with Retained Placenta. Turkish Journal of Veterinary and Animal Sciences, 26: 41-45

Akar, Y. and Yeldiz, H. (2005): Concentrations of some minerals in cows with retained placenta and abortion. Turkish J. Vet. Anim. Sci., 29, 1157-1162.

Ali, M.A.; Lodhi, L.A.; Ahmad, I. and Younas, M. (2009): Serum progesterone and estradiol-17 $\beta$ profiles in Nilli Ravi buffaloes (Bubalus bubalis) with and without retention of fetal membranes. Pak. Vet. J., 29: 64-66.

Ali, M.A.; Lodhi, L.A. and Faiz-ul-Hassan (2012): Serum Progesterone and Estradiol-17 $\beta$ Profiles in Nili Rivi Buffaloes (Bubalus bubalis) with and without Dystocia. Pak. Vet. J., 32(4): 571-574.

Arechiga, C.F.; Vazquez-Flores, S.; Ortiz, O.; Hernandez-Ceron, J.; Porra, A.; McDowell, L.R. and Hansen, P.J. (1998): Effect of injection of beta-carotene or vitamin $\mathrm{E}$ and selenium on fertility of lactating dairy cows. Theriogenology, 50: 65-76.

Arthur, G.H.; Noakes, D.E. and Pearson, H. (1989): Veterinary Reproduction and Obstetrics. $6^{\text {th }}$ 
Ed., Bailliere Tindall. London, UK, pp: 591-599.

Bari, M.Z.; Saeed, M.A.; Bashir, I.N. and Shoaib, H.M. (1996): Comparative study on serum levels of calcium, magnesium and phosphorus in cows with and without retention of placenta. Indian J. Anim. Nutr., 13: 63-66.

Bauer, J.D. (1982): Clinical Laboratory Methods. $9^{\text {th }}$ edition, The C.V. Mosby company, USA.

Dabas, Y.P.S.; Singh, S.P. and Saxena, O.P. (1987): Semen level of minerals in crossbred cows and buffaloes during retained placenta and post partum vaginal prolapse. Indian J. Anim. Reprod., 8: 145-147.

Dann, H.M.; Morin, D.E., Bollero, G.A.; Murphy, M.R. and Drackley, J.K. (2005): Prepartum intake, postpartum induction of ketosis, and periparturient disorders affect the metabolic status of dairy cows. J. Dairy Sci., 88: 3249-3264.

Dobson, H. and Smith R.F. (2000): What is stress, and how does it affect reproduction? Anim. Reprod. Sci., 60: 743-752.

Drackley, J.X. (1999): Biology of dairy cows during the transition period: The final frontier. J. Dairy Sci., 82: 2259-2273.

Elecko, J.; Kacmárik, J.; Halagan, J. and Sevcik, A. (1982): Progesterone and free estradiol-17-beta levels in cows at physiological parturition and at parturition with retained placenta. Folia Vet., 26: 29-37.

El-Nemer, I.Z.; Hazza, N.I. and Emara, S. (2000): Changes in thyroid and sex hormones in serum of pregnant and lactating Egyptian buffaloes, $1^{\text {st }}$ Sci. Conf. Vet. Physio., Beni-Suef., pp 77-82.

El-Wishy, A.B. (2007): The postpartum buffalo: I. Endocrinological changes and uterine involution. Anim. Reprod. Sci., 97: 201-215.

Erb, R.E.; D'Amico, M.F.; Chew, B.P.; Malven, P.V. and Zamet, C.N. (1981): Variables associated with peripartum traits in dairy cows. VIII. Hormonal profiles associated with dystocia. J. Anim. Sci., 52: 346-358.

Farzaneh, F.; Moghaddam, J.A.; Honarmand, K.; Mirshokraei, P. and Mohri, M. (2002): Comparison of some biochemical, hormonal and haematological parameters in cows with and without retained placenta. Abstracts, XXII World Buiatrics Congress, Hannover, Germany, pp. 98.

Gindler, M. and King, J.D. (1972): Rapid colorimetric determination of calcium in fluids with b-methyl blue. Am. J. Clin. Path., 58: 376-380.

Goldenberg, H. (1966): Determination of inorganic phosphorus. Clin. Chem., 12: 871-885.

Graham, T.W.; Thurmond, M.C.; Gershwin, M.E.; Picanso, J.P.; Garvey J.S. and Keen, C.L. (1994): Serum zinc and copper concentrations in relation to spontaneous abortion in cows: implications for human fetal loss. J. Reprod. Fertil., 102: 253-262.

Ham, E.A.; Cirillo, V.J.; Zanetti, M.E. and Kuehl, Jr. F.A. (1975): Estrogen-directed synthesis of specific prostaglandins in uterus. Proc. Nat. Acad. Sci. U.S.A. 72, 1420-1424.

Hattab, S.A. and Abdel Moghney, A.F. (1994): The role of selenium and vitamin $E$ supplementation in reduction of retained bovine placenta. The $6^{\text {th }}$ Ann. Cong. Egypt., Soc. Anim. Reprod. Fert., Cairo, pp: 43- 46.

Herdt, I.H; Wensnig, I.; Haagsman, H.P.; Van Gold, L.M.G. and Breuknik, H.J. (1988): Hepatic triacylglycerol synthesis during a period of fatty liver development in sheep. Anim. Sci., 66: 1997-2013.

Hollender, J.; Sandner, F.; Moller, M. and Dott, W. (2002): Sensetive in door air monitoring of monoterenes using different adsorpents and thermal desorption gas chromatography with mass selective detection. J. chromatography 962 (1-2): 175-81.

Hussain, S.O. (1983): Treatment and prevention of retained placenta in dairy cattle. $15^{\text {th }}$ FAO/SIDA International Postgraduate course on Animal Reproduction, Vol. 2nd, pp: 8-29.

Jorritsma, R.; Jorritsma, H.; Schukken, Y.H. and Wentiuk, H.H. (2000): Relationships between fatty liver and fertility and some periparturient diseases in commercial Dutch dairy herds. Theriogenology, 54: 1065-1074.

Kaczmarowski, M.; Malinowski, E. and Markiewicz, H. (2006): Some hormonal and biochemical blood indices in cows with retained placenta and puerperal metritis. Bull Vet. Inst. Pulawy 50, 89-92.

Kandeil, M.A.; Amin, K.A. and Ali, K.M. (2002): Comparative biochemical studies between retained and non- retained placenta in cows and buffaloes. Egypt. J. Vet. Med. Ass., 62(4): 255-264.

Kankofer, M.; Zdunczyk, S. and Hoedmaker, M. (1996): Contents of triglycerides and cholesterol in bovine placental tissue and in serum as well as plasma concentration of oestrogens in cows with and without retained placental fetal membranes. Reprod. Dom. Anim., 31, 681-683.

Kankofer, M.; Wiercinski, J.; Kedzierski, W. and Mierzynski, R. (1998): The analysis of fatty acids content and phospholipase A2 activity in placenta of cows with and without retained fetal membranes. J. Vet. Med. Series1, 43: 459-465.

Kommisrud, E.; Osteras, O. and Vatn, T. (2005): Blood selenium associated with health and fertility in Norwegian dairy herds. Acta Veterinaria Scandinavica, 46: 229-240. 
Kornmatitsuk, B.; Konigsson, K.; Kindahl, H. and Gustafsson, H. (2000): Clinical signs, body temperature, and hormonal changes in dairy heifers after induction of parturition with PGF2 a. $14^{\text {th }}$ International Congress on Animal Reproduction, Stockholm, 1, p. 179.

Königsson, K.; Gustafsson, $H$. and Kindahl, $H$. (2002): 15-Ketodihydro PGF (2 alpha), progesterone and uterine involution in primiparous cows with induced retained placenta and post-partal endometritis treated with oxytetracycline and flunixin. Reprod. Domest. Anim., 37(1): 43-51.

Kuźma, K.; Kuźma, R.; Malinowski, M. (1996): Relationship between retained placenta and ketosis in dairy cows. XIX World Buiatrics Congress, Germany, pp. 358-360.

Laszlo, K.; Otto, S.; Viktor, J.; Laszlone, T.; Beckers, J.F. and Endre, B. (2009): Examination of some reproductive indices of peripartal period in relation with energy metabolism in dairy cows. Magyar Állatorvosok Lapja, 131: 259-269.

Laven, R.A.; Peters, A. (1996): Bovine retained placenta: aetiology, pathogenesis and economic losses. Vet. Rec., 139, 465-471.

Levis, G.S. (1997): Uterine health and disorders. J. Dairy Sci., 80, 984-994.

Macak, V.; Novotny, F.; Kacmarik, J. and Balent, P. (1999): Relationship between concentrations of NEFA and cholesterol in blood serum of cows with puerperal diseases. Acta VetBeograd, 49: 289-298.

Mandali, G.C.; Patel, P.R.; Dhami, A.J.; Ranal, S.K. and Christi, K.S. (2002): Biochemical profile in buffaloes with periparturient reproductive and metabolic disorders. Indian J. Anim. Reprod., 23: 130-134.

Markiewicz, H.; Kuzma, K. and Malinowski, E. (2001): Predisposing factors for puerperal metritis in cows. Bull Vet. Inst. Pulawy, 45: 281-288.

Matton, P.; Adelakoun, V. and Dufour, J. (1987): Corpus luteum activity and prostaglandin levels after parturition in cows with retained fetal membranes. Canadian J. Anim. Sci., 67: 21-26.

McSporran, K.D.; Lorentz, P.P.; Pryor, W.J. (1977): Plasma zinc levels in sheep in the periparturient period. Res. Vet. Sci., 22(3), 393-394.

Melendez, P.; Donovan, G.A.; Risco, C.A. and Goff, J.P. (2004): Plasma mineral and energy metabolite concentrations in dairy cows fed an anionic prepartum diet that did or did not have retained fetal membranes after parturition. Am. J. Vet. Res., 65 (8), 1071-1076.

Michal, K.; Edward, M. and Hanna, M. (2006): Some hormonal and biochemical blood indices in cows with retained placenta and puerperal metritis. Bull. Vet. Inst. Pulawy, 50: 89-92.

Mohanty, K.C.; Mohanty, B.N.; Ray, S.K.H. and Mohanty, D.N. (1994): Levels of glucose, calcium and alkaline phosphatase in blood with relation to retention of placenta in bovines. Indian J. Anim. Reprod., 15: 21-23.

Naziroglu, M.; Cay, M.; Karatas, F.; Cimtay, I. and Aksakal, M. (1998): Plasma Levels of Some Vitamins and Elements in Aborted Ewes in Elazıg Region. Turk. J. Vet. Anim. Sci., 22, 171-174.

Olujohungbe, A.A.; Bryant, M.J.; Cobby, J.M. and Pope, G.S. (1998): Relationships of peripartum plasma concentrations of progesterone, oestrogens and 13, 14-dihydro-15-keto prostaglandin F2 alpha in heifers and of anatomical measurements of dam and calf with difficulty of calving in early bred Hereford $\mathrm{x}$ Friesian heifers. Anim. Reprod. Sci., 52: 1-16.

Oresnik, A. (1995): Effect of health and reproductive disorders on milk yield and fertility in dairy cow. Bovine Prod., 29: 43-45.

Ospina, P.A.; Nydam, D.V.; Stokol, T. and Overton, T.R. (2010): Evaluation of nonesterified fatty acids and betahydroxybutyrate in transition dairy cattle in the northeastern United States: Critical thresholds for prediction of clinical diseases. J. Dairy Sci., 93: 546-554.

Patel, R.D.; Nema, S.P.; Sheela, T. and Chauhan, R.A.S. (1999): Biochemical changes associated with retention of fetal membranes in buffaloes. Indian J. Anim. Reprod., 20: 35- 39.

Peter, A.T. and Bosu, W.T.K. (1987): Peripartal endocrine changes associated with retained placenta in dairy cows. Theriogenology, 28, 383-394.

Quiroz-Rocha, G.F.; Leblanc, S.; Duffield, T.; Wood, D.; Leslie, K. E. and Jacobs, R. M. (2009): Evaluation of prepartum serum cholesterol and fatty acids concentrations as predictors of postpartum retention of the placenta in dairy cows. J. Am. Vet. Med. Assoc., 234: 790-793.

Rabbani, R.A.; Ahmad, I.; Lodhi, L.A.; Ahmad, N. and Muhammad, G. (2010): Prevalence of various reproductive disorders and economic losses caused by genital prolapse in buffaloes. Pak. Vet. J., 30: 44-48.

Rasmussen, F.E.; Wiltbank, M.C.; Christensen, J.O. and Grummer, R.R. (1996): Effects of fenprostalene and estradiol-17 benzoate on parturition and retained placenta in dairy cows and heifers. J. Dairy Sci., 79: 227-234.

Roche, J.F. (2006): The effect of nutritional management of the dairy cow on reproductive efficiency. Anim. Reprod. Sci., 96(3-4): 282296.

Rukkwamsuk, I.; Wensing, I. and Geelen, M.J.H. (1998): Effect of overfeeding during the dry period on regulation of adipose tissue 
metabolism in dairy cows during the periparturient period. J. Dairy Sci., 81: 29042911.

Sabry, H.A.; Shalaby, S.I.A. and Hussain, S.G. (1997): Retained placenta in an imported Friesian herd under Egyptian conditions. Vet. Med. J., 45: 121-127.

Samad, H.A.; Ali, C.S.; Rehman, N.U.; Ahmad, A. and Ahmad, N. (1987): Clinical incidence of reproductive disorders in buffalo. Pak. Vet. J., 7: 16-19.

Seifi, H.A.; Dalir-Naghadeh, B.; Farzaneh, N.; Mohri, M. and Gorji-Dooz, M. (2007): Metabolic changes in cows with or without retained fetal membranes in transition period. Journal of Veterinary Medical Association, Physiol Pathol Clin Med. 54(2): 92-97.

Semacan, A. and Sevinc, M. (2005): Liver function in cows with retained placenta. Turk. J. Vet. Anim. Sci., 29: 775-778.

Snedecore, G.W. and Cochran, W.C. (1987): Statistical Methods. $8^{\text {th }}$ Ed., Loweastate Univ. Press Ames, Lawa, USA.

Subandrio, A.J. and Noakes, D.E. (1997): Neutrophil migration into the uterine lumen of the cow: the influence of endogenous and exogenous sex steroid hormones using two intrauterine chemoatrtractans. Theriogenology, 47: 825-835.

Thomas, D.G.; Miller, J.K.; Mueller, F.J.; Erickson, B.H. and Madsen, F.C. (1992): Effects of vitamin $\mathrm{E}$ and iron supplementation on progesterone and estrogen concentrations in relation to retained placenta. J. Dairy Sci., 75 (Suppl. 1), 297.

Tillard, E., Humblot, P.; Faye, B.; Lecomte, P.; Dohoo, I. and Bocquier, F. (2008): Postcalving factors affecting conception risk in Holstein dairy cows in tropical and sub-tropical conditions. Theriogenology, 69 (4): 443-457.

Uchide, T.; Tohya, Y.; Onda, K.; Matsuki, N.; Inaba, M. and Ono, K. (1997): Apolipoprotein B concentrations in lipoproteins in in cows. J. Vet. Med. Sci., 59: 711-714.

Wango, E.O.; Heap, R.B. and Wooding, F.B.P. (1992): Regulation of steroid synthesis and metabolism in isolated binucleate cells of the placenta in sheep and goats. J. Reprod. Fert., 94: 203-211.

Watson, D. (1960): Determination of serum cholesterol. Clin. Chem. Act., 5: 637

Weber, P.S.D.; Preisler, M.T.; Kizilkaya, K. and Burton, J.l. (2000): Cortisol correlates with neutrophil CD62L mRNA abundance at parturition. Proceedings of International Symposium on Immunology of Ruminant Mammary Gland, Stresa, Italy, pp. 171-173.

Wilde, D. (2006): Influence of macro and micro minerals in the peri-parturient period on fertility in dairy cattle. Anim. Reprod. Sci., 96: 240-249.

Wischral, A.; Verreschi, I.T.N.; Lima, S.B.; Hayashi, L.F. and Barnabe, R.C. (2001): Pre-parturition profile of steroids and prostaglandin in cows with or without fetal membrane retention. Anim. Reprod. Sci., 67: 181-188.

Wooding, F.B.P.; Morgan, G.; Monaghan, S.; Hamon, M. and Heap, R.B. (1996): Functional specialization in the ruminant placenta: evidence for two populations of fetal binucleate cells of different selective synthetic capacity. Placenta, 17: 75-86.

Yokus, B.; Cakir, D.; Icen, H.; Durak, H. and Bademkiran, S. (2010): Prepartum and postpartum serum mineral and steroid hormone concentrations in cows with dystocia. YYU Veteriner Fakultesi Dergisi, 21: 185-190.

Zhang, W.C.; Nakao, T.; Moriyoshi, M.; Nakada, K.; Ribadu, A.Y.; Ohtaki, T. and Tanaka, Y. (1999): Relationship of maternal plasma progesterone and estrone sulphate to dystocia in Holstein Frisian Heifers and cows. J. Vet. Med. Sci., 61: 909-913.

\footnotetext{
الصورة الهرمونية والبيوكيميائية بمصل الجاموس كقيم تتبوية بحدوث احتباس المشيمة

عبل الخالق عطية نصرة ، طارق عبل السلام حسن ، طه عبل القادر غطاس

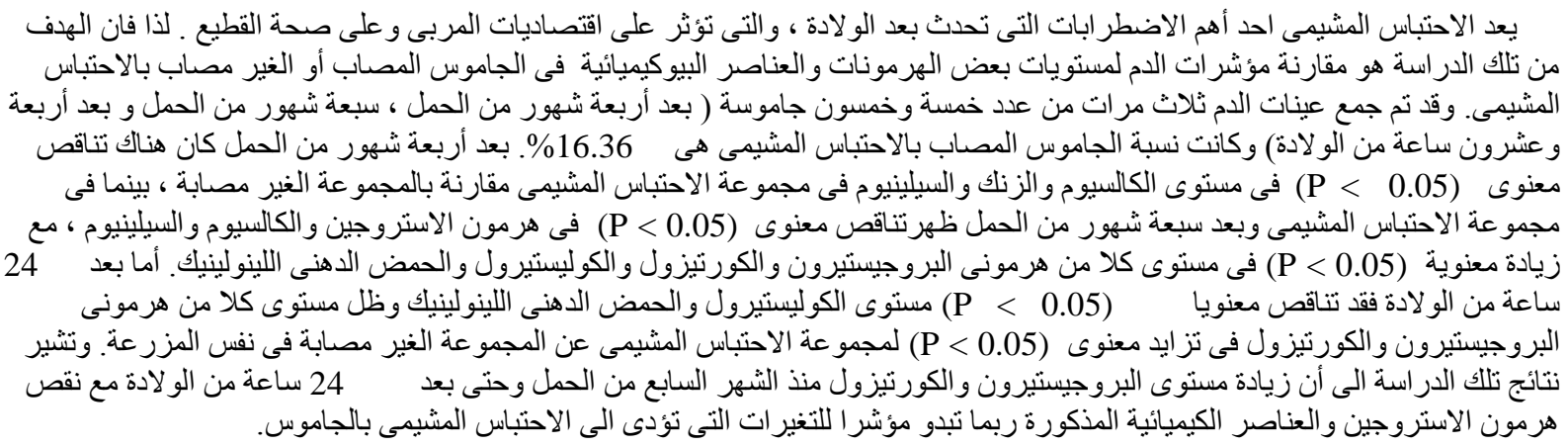

